\title{
HUBUNGAN PERILAKU MAKAN DENGAN STATUS GIZI PADA REMAJA PUTRI DI SMAN 2 TAMBANG
}

\author{
Rini Hariani Ratih, Sara Herlina, Yusmaharani \\ Universitas Abdurrab, Jl. Riau Ujung no 73 Pekanbaru, 085278166724 \\ Email: Rini.hariani.ratih@univrab.ac.id
}

\begin{abstract}
ABSTRAK
Data Riskesdas 2018 menunjukkan bahwa 25,7\% remaja usia 13-15 tahun dan 26,9\% remaja usia 16-18 tahun dengan status gizi pendek dan sangat pendek. Selain itu terdapat 8,7\% remaja usia 13-15 tahun dan 8,1\% remaja usia 16-18 tahun dengan kondisi kurus dan sangat kurus. Sedangkan prevalensi berat badan lebih dan obesitas sebesar 16,0\% pada remaja usia 13-15 tahun dan 13,5\% pada remaja usia 16-18 tahun. Data tersebut merepresentasikan kondisi gizi pada remaja di Indonesia yang harus diperbaiki. Berdasarkan baseline survey UNICEF pada tahun 2017, ditemukan adanya perubahan pola makan dan aktivitas fisik pada remaja. Gizi merupakan salah satu faktor utama penentu kualitas hidup dan sumber daya manusia. Tujuan penelitian Untuk mengetahui hubungan perilaku makan terhadap status gizi pada siswi SMAN 2 Tambang 2018. Penelitian ini mengunakan jenis kuantitatif analitik dengan desain cross sectional. Populasi pada penelitian ini adalah seluruh siswa putri SMAN 2 Tambang dari kelas XI sebanyak 240 orang dengan sampel sebanyak 71 orang. Hasil uji Chi Square didapatkan nilai $p=0,01(\leq 0,05$. Ada hubungan yang signifikan perilaku makan dengan status gizi pada remaja putr di SMAN 2 Tambang.
\end{abstract}

Kata Kunci : perilaku makan; status gizi; remaja putri

\section{RELATIONSHIP BETWEEN EATING BEHAVIOR WITH NUTRITIONAL STATUS IN FEMALE ADOLESCENT AT TAMBANG STATE SENIOR HIGH SCHOOL 2}

\begin{abstract}
According to the report of Indonesian Health Research in 2018 showed that 25.7\% of adolescents aged 13-15 years and $26.9 \%$ of adolescents aged 16-18 years have a short and very short nutritional status. In addition, there were $8.7 \%$ adolescents aged $13-15$ years and 8.1\% adolescents aged 16-18 years with thin and very thin conditions. Meanwhile, the prevalence of overweight and obesity was $16.0 \%$ in adolescents aged $13-15$ years and $13.5 \%$ in adolescents aged $16-18$ years. Nutrition is one of the main factors determining the quality of life and human resources. Nutrients are chemicals found in food that the body needs to maintain health and immunity; adolescents are one of the groups that are prone to experiencing nutritional problems. The research objective was to determine the relationship between eating behavior and the nutritional status of students at SMAN 2 Tambang 2018. This research method used a quantitative analytic research type, with a cross sectional study design. The populations in this study were all 12 students of Tambang State Senior High School 2 from class XI totaling 240 students. The sample in this study was some of the 71 class students. The results of the Chi Square test showed that the value of $p=0.01(\leq 0.05)$, this means that statistically there is a relationship between eating behavior and nutritional status in young girls.
\end{abstract}

Keywords: eating behavior; nutritional status; female adolescent

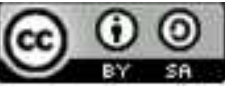

Jurnal SMART Kebidanan licensed under a Creative Commons Attribution-ShareAlike 4.0 International License 


\section{LATAR BELAKANG}

Gizi merupakan salah satu faktor utama penentu kualitas hidup dan sumber daya manusia. Penentu zat gizi yang baik terdapat pada jenis pangan yang baik dan disesuaikan dengan kebutuhan tubuh. Zat gizi adalah bahan kimia yang terdapat dalam bahan pangan yang dibutuhkan tubuh untuk menjaga kesehatan dan daya tahan tubuh, remaja termasuk kelompok yang rentan mengalami permasalahan gizi (Ubro, 2014)

Remaja (adolescence) merupakan masa dimana terjadi transisi masa kanak-kanak menuju dewasa, biasanya antara 13 sampai 20 tahun. Pada masa ini individu mengalami perkembangan fisik, psikologi dan pola identifikasi dari anak-anak menjadi dewasa. Peralihan terjadi dari ketergantungan sosial dan ekonomi yang penuh kepada orang Perubahan fisik ditandai dengan pertumbuhan badan yang pesat dan matangnya organ reproduksi. Perubahan-perubahan yang terjadi pada remaja cenderung akan menimbulkan berbagai permasalahan dan perubahan perilaku di kehidupan remaja. Salah satu bentuk perubahan perilaku pada masa remaja adalah perubahan perilaku makan, baik mengarah perilaku makanan yang sehat ataupun cenderung mengarah kepada perilaku makan yang tidak sehat.(Potter PA, 2012)

Masalah gizi pada remaja yang terjadi karena kebiasaan makan yang salah,antara lain obesitas, kurang gizi kronis, dan kekurangan zat gizi mikro seperti anemia gizi. Menurut (Poltekes Depkes I, 2012), hal ini disebabkan pada masa remaja bukan lagi seorang anak dan juga bukan seorang dewasa. Masa ini merupakan masa strategis karena memberi waktu kepada remaja untuk membentuk gaya hidup dan menentukan pola perilaku, nilai-nilai, dan sifat-sifat yang sesuai dengan yang diinginkan.

Masalah gizi pada remaja di pengaruhi oleh beberapa faktor diantaranya adalah pengetahuan, perilaku makan dan body image. Semakin tinggi pengetahuan seseorang tentang gizi, maka orang tersebut akan semakin memperhitungkan jumlah zat gizi dan jenis bahan makanan yang dipilih untuk dikonsumsi. Pengetahuan seseorang tentang gizi dapat diperoleh melalui pendidikan formal maupun informal (Nurrahmi, 2012)

Menurut hasil penelitian (Florence, 2017) yang di lakukan pada Mahasiswa TPB Sekolah Bisnis Dan Manajemen Institut Teknologi Bandung terdapat hubungan yang kuat antara pengetahuan gizi dan pola konsumsi dengan status gizi pada mahasiswa TPB di Sekolah Bisnis dan Manajemen Institut Teknologi Bandung. Berdasarkan hasil penelitian diatas hasil dari penelitian Florence sesuai dengan hasil penelitian ini yang mana ada hubungan antara pola makan dengan status gizi pada remaja putri.

Perilaku makan tidak baik adalah kebiasaan mengonsumsi makanan yang tidak memberi semua zat-zat gizi esensial seperti karbohidrat, lemak dan protein yang dibutuhkan dalam metabolisme tubuh. Perilaku makan tidak baik seperti makan yang tidak teratur baik waktu ataupun jenis makanan, diet penurunan berat badan, binge eating, kebiasaan makan pada malam hari dapat merusak kesehatan dan kesejahteraan psikologis individu (Sarintohe, 2016)

Berdasarkan data yang didapatkan dari Badan Koordinasi Keluarga Berencana Nasional (BKKBN, 2013), pada bulan Juli 2013 jumlah remaja Indonesia yang berusia 10 sampai 24 tahun mencapai 64 juta jiwa.Provinsi Riau, terdapat beberapa kota yang salah satunya kota Pekanbaru yang memiliki jumlah remaja rentang usia 10 sampai 24 tahun paling banyak dibandingkan dengan kota lainnya, yaitu berjumlah 282.026 jiwa (Badan Pusat Statistik, 2015)

Data Riset Kesehatan Dasar (Riskesdas), 2018 menunjukkan bahwa 25,7\% remaja usia 13-15 tahun dan 26,9\% remaja usia 16-18 tahun dengan status gizi pendek dan sangat pendek. Selain itu terdapat 8,7\% remaja usia $13-15$ tahun dan 8,1\% remaja usia 16-18 tahun dengan kondisi kurus dan sangat kurus. Sedangkan prevalensi berat badan lebih dan obesitas sebesar $16,0 \%$ pada remaja usia 13-15 tahun dan 13,5\% pada remaja usia 16-18 tahun.

Adapun faktor internal yang mempengaruhi perilaku makan adalah faktor fisik dan faktor 
psikologis. Sedangkan faktor faktor eksternal yang mempengaruhi perilaku makan adalah budaya, ekonomi, norma sosial, pengetahuan, dan media ataupun periklanan. Khususnya pada remaja puteri mulai berfikir dan lebih sensitif terhadap perubahan ukuran, bentuk tubuh dan penampilan. Faktor psikologis yang mempengaruhi perilaku makan seseorang

\section{METODE}

Penelitian ini mengunakan jenis penelitian kuantitatif analitik, dengan jenis desain Cross Sectional Study dengan unsur variabel independen dan variabel dependen dinyatakan dalam waktu yang sama kepada responden. (Nursalam, 2012). Populasi pada penelitian ini adalah seluruh siswa putri SMAN 2 Tambang dari kelas XI sebanyak 12 kelas sebanyak 240 siswa. Sampel dalam penelitian ini adalah sebagian dari siswa kelas sebanyak 71 orang dengan teknik pengambilan sampel simpel random sampling, yakni teknik pengambilan sampel dengan cara memilih sampel secara acak dan sederhana.

Kriteria inklusi dalam penelitian ini yaitu: siswa putri SMAN 2 Tambang dan bersedia menjadi responden. Alat ukur untuk pengumpulan data yang dipakai pada penelitian ini adalah kuisioner dan IMTdengan Z Score. Kuisioner pada penelitian ini, sudah dapat dibuat sedemikian rupa sehingga diharapkan dapat menjawab pertanyaan dari penelitian yang dilakukan. Analisis penelitian ini menggunakan uji statistik yaitu Chi square dengan tingkat kepercayaan $5 \%$.

\section{HASIL}

Hasil penelitian yang dilakukan di SMAN 2 Tambang tentang perilaku makan dan status gizi pada remaja putri dapat dilihat dari tabel berikut:

Tabel. 1 Distribusi Frekuensi Perilaku Makan $(n=71)$

\begin{tabular}{lcc}
\hline $\begin{array}{c}\text { Perilaku } \\
\text { Makan }\end{array}$ & $\begin{array}{c}\text { Frekuensi } \\
(\mathrm{n})\end{array}$ & $\begin{array}{c}\text { Persentase } \\
(\%)\end{array}$ \\
\hline Positif & 40 & 56,3 \\
Negatif & 31 & 43,7 \\
\hline \multicolumn{1}{c}{ Jumlah } & 71 & 100 \\
\hline
\end{tabular}

Tabel 1 menunjukkan bahwa sebagian besar responden dengan perilaku makan positif yaitu sebanyak 40 orang $(53,3 \%)$ dan responden dengan perilaku makan negative sebanyak 31 orang $(43,7 \%)$. Sedangkan status gizi pada responden dapat dilihat pada tabel 2 berikut ini;

Tabel. 2 Distribusi Frekuensi Status Gizi $(n=71)$

\begin{tabular}{lcc}
\hline Status Gizi & $\begin{array}{c}\text { Frekuensi } \\
(\mathrm{n})\end{array}$ & $\begin{array}{c}\text { Persentase } \\
(\%)\end{array}$ \\
\hline Normal & 44 & 61,97 \\
Tidak Normal & 27 & 38,03 \\
\hline Jumlah & 71 & 100 \\
\hline
\end{tabular}

Tabel 2 menunjukkan bahwa sebagian besar responden dengan status gizi normal yaitu sebanyak 44 orang $(61,97 \%)$ dan responden dengan status gizi tidak normal sebanyak 27 orang (38,03\%).

Analisis bivariat bertujuan untuk mengetahui hubungan perilaku makan responden terhadap status gizi pada remaja puteri di SMAN 2 Tambang. Adapaun hasil analisis bivariate terdapat pada tabel 3 berikut ;

\section{Tabel. 3 Hubungan Perilaku Makan Terhadap Status Gizi $(n=71)$}

\begin{tabular}{lccccccc}
\hline \multirow{2}{*}{$\begin{array}{c}\text { Perilaku } \\
\text { Makan }\end{array}$} & \multicolumn{3}{c}{ Status gizi } & \multicolumn{2}{l}{ Total } & $\mathrm{p}$ \\
\cline { 2 - 7 } & Normal & \multicolumn{3}{c}{$\begin{array}{c}\text { Tidak } \\
\text { Normal }\end{array}$} & & & \\
\cline { 2 - 7 } & $\mathrm{n}$ & $\%$ & $\mathrm{n}$ & $\%$ & $\mathrm{~N}$ & $\%$ & \\
\hline Positif & 30 & 75 & 10 & 25 & 40 & 100 & 0,01 \\
Negatif & 14 & 45,2 & 17 & 54,8 & 31 & 100 & \\
\hline & 44 & 62 & 27 & 38 & 71 & &
\end{tabular}

Tabel 3 menujukkan bahwa hubungan perilaku makan responden status gizi di dapatkan hasil $p(0,01)<\alpha(0,05)$ yang berarti terdapat hubungan antara perilaku makan responden terhadap status gizi di SMAN 2 Tambang.

\section{PEMBAHASAN}

Status Gizi Remaja di SMAN 2 Tambang Distribusi status gizi terlihat sebagian besar 
responden dengan status gizi Normal yaitu sebanyak 44 orang (62\%). Sedangkan untuk responden dengan status gizi tidak normal berjulamlah 27 orang (37\%).

Zat gizi yang diperoleh melalui konsumsi pangan harus sesuai dan cukup bagi kebutuhan tubuh (Almatsier, 2011). Energi dalam tubuh manusia dapat timbul karena adanya pembakaran karbohidrat, protein, dan lemak. Sehingga manusia membutuhkan zat-zat makanan yang cukup untuk memenuhi kecukupan energinya

Status gizi adalah salah satu unsur penting dalam membentuk status kesehatan. Status gizi (nutritional satus) adalah keadaan yang diakibatkan oleh keseimbangan antara asupan zat gizi dari makanan dan kebutuhan zat gizi oleh tubuh. Status gizi sangat dipengaruhi oleh asupan gizi (Depkes RI, 2018)

Pada dasarnya status gizi seseorang ditentukan berdasarkan konsumsi gizi dan kemampuan tubuh dalam menggunakan zat-zat gizi tersebut. Status gizi normal menunjukkan bahwa kualitas dan kuantitas makanan yang telah memenuhi kebutuhan tubuh. Seseorang yang berada di bawah ukuran berat badan normal memiliki risiko terhadap penyakit infeksi, sedangkan seseorang yang berada di atas ukuran normal memiliki risiko tinggi penyakit degeneratif. Oleh karena itu, diharapkan lebih memperhatikan asupan makanan yang dikonsumsi. Sebaiknya memilih jenis makanan yang sehat dan bergizi sehingga dapat memenuhi kebutuhan gizi seseorang (Amsi \& Muhajirin, 2011)

Konsumsi makanan berpengaruh terhadap status gizi seseorang. Status gizi normal terjadi bila tubuh memperoleh cukup zat-zat gizi yang digunakan secara efisien, sehingga memungkinkan pertumbuhan fisik, perkembangan otak, kemampuan kerja dan kesehatan secara umum pada tingkat setinggi mungkin. Status gizi tidak normal terjadi bila tubuh mengalami kekurangan satu atau lebih zatzat gizi esensial. Status gizi merupakan gambaran secara makro akan zat gizi tubuh kita, termasuk salah satunya adalah zat besi. Dimana bila status gizi tidak normal dikhawatirkan status zat besi dalam tubuh juga tidak baik. Masalah gizi pada remaja yang terjadi karena kebiasaan makan yang salah, antara lain obesitas, kurang gizi kronis, dan kekurangan zat gizi mikro seperti anemia gizi. Menurut (Depkes RI, 2010), hal ini disebabkan pada masa remaja bukan lagi seorang anak dan juga bukan seorang dewasa. Masa ini merupakan masa strategis karena memberi waktu kepada remaja untuk membentuk gaya hidup dan menentukan pola perilaku, nilainilai, dan sifat-sifat yang sesuai dengan yang diinginkan. Berdasarkan hasil penelitian dari Cahyaningrum. H.D., 2013 kategori status gizi siswi SMA Batik 1 surakarta dikelompokkan menjadi 3 kategori yaitu kurang, normal, dan lebih. Berdasarkan hasil SPSS bahwa sebagian besar sampel memiliki status gizi normal yaitu 37 siswi $(55,2 \%)$ sedangkan sampel yang memiliki status gizi kurang yaitu 12 siswi $(17,9 \%)$ daan untuk status gizi lebih yaitu 18 siswi (26,8\%). Beberapa sampel megalami status gizi kurang hal ini mungkin disebabkan karena sikap sampel yang terlau menbatasi porsi makan.

Hubungan Perilaku makan Dengan Status Gizi. Hasil uji Chi Square didapatkan nilai $p=0,01(\leq 0,05)$, ini berarti secara statistic ada hubungan perilaku makan dengan status gizi pada remaja putri. Remaja putri yang memiliki perilaku makan berisiko mengalami gangguan makan cenderung lebih banyak mengalami status gizi tidak normal (kurus dan gemuk) dibandingkan dengan status gizi normal.

Masalah gizi pada remaja di pengaruhi oleh beberapa faktor diantaranya adalah pengetahuan, perilaku makan dan body image. Semakin tinggi pengetahuan seseorang tentang gizi, maka orang tersebut akan semakin memperhitungkan jumlah zat gizi dan jenis bahan makanan yang dipilih untuk dikonsumsi. Pengetahuan seseorang tentang gizi dapat diperoleh melalui pendidikan formal maupun informal (Nurrahmi, 2012) Penelitian ini membahas tentang perilaku makan terhadap status gizi pada remaja putri.

Perilaku makan merupakan suatu respon perilaku yang berhubungan dengan makanan yang dikonsumsi mencakup jenis makanan, jumlah dan waktu mengonsumsi makanan. Faktor yang mempengaruhi perilaku makan secara langsung adalah faktor individu dan faktor lingkungan. Faktor tersebut akan memperlihatkan gaya hidup seseorang yang 
ditunjukkan dengan perilaku makan yang pada akhirnya berpengaruh terhadap status gizi remaja putri (Gibney MJ, 2012)

Kebiasaan makan dipengaruhi oleh beberapa faktor lingkungan seperti lingkungan budaya, alam serta populasi. Kebiasaan makan dipengaruhi oleh lingkungan khususnya budaya, secara umum sulit untuk diubah. Kebanyakan orang membatasi makanan yang mereka makan sesuai dengan yang mereka sukai atau nikmati. Remaja telah mempunyai pilihan sendiri terhadap makanan yang disenangi. Pada masa remaja kebiasaan makan telah terbentuk. Pemberian makanan yang benar pada anak usia sekolah harus dilihat dari banyak aspek, seperti ekonomi, sosial, budaya, agama, disamping aspek medik dari anak itu sendiri. Makanan pada usia sekolah harus serasi, selaras dan seimbang. Serasi artinya sesuai dengan tingkat tumbuh kembang anak. Selaras adalah sesuai dengan kondisi ekonomi, sosial budaya serta agama dari keluarga. Sedangkan seimbang artinya nilai gizinya harus sesuai dengan kebutuhan berdasarkan usia dan jenis makanan seperti karbohidrat, protein, dan lemak. Kebiasaan makan biasanya akan berubah saat masa remaja. Pada puncak kecepatan pertumbuhan, remaja makan lebih sering dan banyak dari biasanya. Namun kebiasaan ini akan berkurang seiring dengan terlewatinya growth spurt (Sayogo, 2014)

Menurut Masdewi, 2011 perilaku makan berpengaruh secara signifikan terhadap status gizi remaja putri, hal ini menunjukkan bahwa perilaku makan yang baik, maka asupan zat gizi yang dibutuhkan oleh tubuh akan terpenuhi sehingga status gizi remaja putri menjadi lebih baik.

Penelitian ini sesuai dengan hasil penelitian (Afrina et al., 2019) Hasil uji Chi Square didapatkan nilai $p=0,000(\leq 0,05)$, ini berarti secara statistik ada hubungan perilaku makan dengan status gizi pada remaja putri. Ada hubungan perilaku makan dengan status gizi pada remaja putri.

Perilaku makan berpengaruh secara signifikan terhadap status gizi remaja putri. Hal ini menunjukkan bahwa jika perilaku makan baik, maka asupan zat gizi yang dibutuhkan oleh tubuh akan terpenuhi sehingga status gizi remaja putri menjadi lebih baik.

Berbeda dengan penelitian yang dilakukan oleh (Pujiati et al., 2015) di dapatkan hasil uji statistic $p$ value $0,331(>0,05)$ yang berarti tidak adanya hubungan antara perilaku makanan dengan status gizi pada remaja putri, hal ini di lihat dari responden pada kelompok yang perilaku makan tidak baik Sebagian mempunyai status gizi normal.

Kecukupan gizi remaja akan terpenuhi dengan pola makan yang beragam dan gizi seimbang. Modifikasi menu terhadap jenis olahan pangan dengan memperhatikan jumlah dan sesuai kebutuhan gizi pada usia remaja sangat membutuhkan makanan yang sangat bergizi. Makanan yang dipilih dengan baik setiap hari akan memberikan semua zat gizi yang diperlukan untuk fungsi normal tubuh, sebaliknya makanan yang tidak di pilih dengan baik akan memberi dampak tubuh mengalami kekurangan gizi esensial tertentu. (Darmayanti et al., 2017)

\section{KESIMPULAN DAN SARAN}

Remaja putri di SMAN 2 Tambang sebagian besar memiliki perilaku makan yang positif dan sebagian besar dengan status gizi normal. Ada hubungan perilaku makan dengan status gizi pada remaja putri di SMAN 2 Tambang. Peneliti selanjutnya diharapkan melakukan penelitian tentang status gizi remaja puteri dengan memperhatikan faktor-faktor lain.

\section{REFERENSI}

Afrina, Muliyati, H., \& Aziz, D. S. (2019). Hubungan perilaku makan dengan status gizi pada remaja putri di SMK Negeri 1 Palu. CHMK HEALTH JOURNAL, $3(2)$.

Almatsier, S. (2011). Prinsip Dasar IImu Gizi. Penebar Swadaya.

Amsi \& Muhajirin. (2011). Gizi dan makanan sehat. selemba medika.

Badan Pusat Statistik 2015. (2015). Badan Pusat Statistik 2015.

Cahyaningrum. H.D. (2013). Hubungan Antara Body Image Dengan Status Gizi Pada Remaja Putri Kelas Xi Ips Di Sma Batik 1 Surakarta. Skripsi: Universitas Muhammadiyah Surakarta.

Darmayanti, D., Pritasari, \& Tri, N. (2017). Gizi dalam Daur 
Kehidupan (B. . Darmanto \& Sapriyad (eds.)). Pusat Pendidikan Sumber Daya Manusia Kesehatan Badan Pengembangan dan Pemberdayaan Sumber daya Manusia Kesehatan.

Depkes RI. (2010). Profil Kesehatan Indonesia.

Depkes RI, D. (2018). Data dan Informasi - Profil Kesehatan Indonesia (Data and Information Indonesia Health Profil). Profil Kesehatan Indonesia 2017.

Florence. (2017). Hubungan Pengetahuan Gizi dan Pola Konsumsi terhadap Status Gizi pada Mahasiswa TPB di Sekolah Bisnis dan Manajemen Institut Teknologi Bandung. Fakultas Teknik Universitas Pasundan.

Gibney MJ, M. M. K. J. A. L. (2012). Gizi Kesehatan Masyarakat. EGC.

Masdewi, M. T. (2011). Korelasi perilaku makan dan status gizi terhadap prestasi belajar siswa program akselerasi di SMP. Journal Teknologi Dan Kejuruan, 34(2).

Nurrahmi. (2012). Kolesterol Tinggi. Familia.

Nursalam. (2012). Konsep dan Penerapan Metodologi Penelitian IImu Keperawatan: Pedoman skripsi, Tesis, dan Instrumen Penelitian Keperawatan (2nd ed.). Salemba Medika.
Poltekes Depkes I. (2012). Kesehatan Remaja Problem dan Solusinya. elemba medika.

Potter PA, P. A. (2012). Fundamental Keperawatan. EGC.

Pujiati, Arneliwati, \& Rahmalia, S. (2015). Hubungan Antara Perilaku Makan Dengan Status Gizi Pada Remaja Putri. Jurnal Online Mahasiswa, 2(2). https://doi.org/10.12816/0013114

Riset Kesehatan Dasar (Riskesdas). (2018). Badan Penelitian dan Pengembangan Kesehatan Kementerian RI tahun 2018. .

Sarintohe, P. (2016). Teori Sosial Kognitif dalam Menjelaskan Perilaku Makan Sehat pada Anak yang Mengalami Obesitas. Sosiains.

Sayogo. (2014). Gizi dan Pertumbuhan Remaja. Fakultas Kedokteran Universitas Indonesia.

Ubro, I. (2014). Ungan Antara Asupan Energi Dengan Hubstatus Gizi Mahasiswa Program Studi Pendidikan Dokter Angkatan 2013 Fakultas Kedokteran Universitas Sam Ratulangi. Jurnal EBiomedik, https://doi.org/10.35790/ebm.2.1.2014.3753 